\title{
Allelopathic INFluenCe OF RESIDUES FROM Sphagneticola trilobata ON WEEDS AND CROPS ${ }^{1}$
}

\author{
A Influência dos Resíduos de Sphagneticola trilobata em Plantas Daninhas e Culturas \\ HERNÁNDEZ-ARO, M. ${ }^{2}$, HERNÁNDEZ-PÉREZ, R. ${ }^{3}$, GUILLÉN-SÁNCHEZ, D. ${ }^{4}$, and
TORRES-GARCIA, S. ${ }^{2}$
}

\begin{abstract}
The allelopathic effect studied in many cultures has currently generated great expectations that displayed a natural and environmentally friendly tool for weed management using bioherbicides. The objective of this work was to assess allelopathic influence of residues of $S$. trilobata on the germination and growth of weeds, as well as their relation with some crops and effects on soil properties. Results show that residues from S. trilobata have inhibited the germination of weeds $(31.6-72 \%)$, increasingly with the applied dose. All residue doses of this specie have inhibited dicotyledonous germination, but only maximum concentration has affected monocotyledons. The residues did not affect onion germination, but stimulated it in radish and tomato, while the dose applied at $50 \%$ produced tomato stimulation and inhibition of cabbage. The effects of residues on hypocotyl growth in different crops showed changes in species response. For onion, the three doses had negative effects on the growth of hypocotyl, while tomato was stimulated. For radish, the growth was hindered by any dose applied, and were only different (50 and $100 \%$ ) compared to control. For cabbage, only hypocotyl length was stimulated, when maximum dose $(100 \%)$ was applied. For the radicle growth, in onion and radish no differences were found compared to control. While the tomato radicle growth was inhibited, in cabbage, all doses encouraged the elongation of the radicle. The dry mass of weed was affected by increased dose of residue $\left(0.49-8.8 \mathrm{~g} \mathrm{~m}^{-2}\right)$, however the soil microflora was stimulated, while the population of Azotobacter spp. was not affect. Some soil properties were affected, the level of organic material, $\mathrm{Na}+$ and electrical conductivity were increased, while $\mathrm{pH}\left(\mathrm{H}_{2} \mathrm{O}\right)$ decreased a bit, however it remained basic.
\end{abstract}

Keywords: allelopathy, residues, Azotobacter, soil microflora.

RESUMO - Atualmente, o efeito alelopático estudado em muitas culturas tem gerado grandes expectativas que exibiam uma ferramenta natural e ambientalmente amigável para manejo de plantas daninhas usando os bioherbicidas. O objetivo deste trabalho foi avaliar a influência alelopático de resíduos de S. trilobata na germinação e crescimento de ervas daninhas, bem como sua relação com algumas culturas e os efeitos sobre as propriedades do solo. Os resultados mostram, que os residuos de S. trilobata produziram uma inibição da germinação das ervas daninhas (31,6 - 72\%), que aumenta com a dose aplicada. Todas as doses de residuos desta espécie, inibiu a germinação dicotiledóneas, mas apenas a concentração máxima afectar as monocotiledóneas. Os resíduos não afecta a germinação de cebola, mas estimulada em rabanete, tomate, enquanto a dose de $50 \%$ de estimulação produzida de tomate e a inibição da couve. O efeito dos resíduos relativamente ao crescimento do hipocótilo nas diferentes culturas mostraram alterações na resposta por espécie. Em cebola as três doses de ter um efeito negativo no hipocótilo, enquanto o tomate foi estimulada. Para o rabanete o crescimento foi retardado com qualquer dose aplicada, apenas foram diferentes (50 e 100\%) em relação a testemunhar. Em repolho, só foi estimulante comprimento do hipocótilo, quando a dose máxima (100\%) foi aplicado. Para o crescimento radicular, na cebola e rabanete não foram

Recebido para publicação em 24.8.2015 e aprovado em 12.10.2015.

2 Central University "Marta Abreu" of Las Villas (UCLV). Faculty of Agricultural Sciences. Agronomy, Santa Clara, Cuba, <santaclara57@yahoo.es>; ${ }^{3}$ Agrobiothenology Center. Fitozoo Corporate. Emiliano Zapata, Texcoco, México; ${ }^{4}$ Higher School Education. Xalostoc (EESX). Autonomous Morelos University. Street Nicolás, Cuautla, Xalostoc, Ayala. Morelos, Mexico. PC:62740. 
encontradas diferenças relação a testemunhar. Enquanto o crescimento radicular tomate foi inibida, diferente do repolho, onde todas as doses produzir o alongamento da radicula. A massa seca de plantas daninhas foi afetada pelo aumento da dose de residuo $\left(0,49-8,8 \mathrm{~g} \mathrm{~m}^{-2}\right)$, no entanto, a microflora do solo foi estimulada, enquanto a população de Azotobacter spp. não foram afetar. Algumas propriedades do solo foram afectados, o nivel de material orgânico, $\mathrm{Na}+$ e condutividade eléctrica foram aumentadas, enquanto que o $\mathrm{pH}\left(\mathrm{H}_{2} \mathrm{O}\right)$ diminuiram um pouco, no entanto, continua a ser básica.

Palavras-chave: alelopathy, resíduos, Azotobacter, microflora do solo.

\section{INTRODUCTION}

Many undesirable plant species in the field have allelochemicals able to control other weeds when applied directly as waste or as extract to the soil (Akhtar et al., 2014).

Allelopathic secondary metabolites are typically released into the soil rhizosphere under appropriate conditions, although they can also be passed through the air as volatiles. Allelopathic compounds can be released into the soil by a variety of mechanisms that include decomposition of residues, root exudation and volatilization (Weston, 2005).

Some species belonging to the Asteraceae, as Wedelia glauca, have been reported as having allelopathic potential under controlled conditions and that at least some of phytotoxins are soluble and they can be released into the aqueous extract from leaves (Sobrero et al., 2004).

Other species, such as S. trilobata, a perennial weed originating from tropical Central and South America, were also considered invasive plants in southern China (Lijun et al., 2010). Their seed production is very low, but they can rapidly spread by producing new plants from nodes.

The aggressive growth habit, tolerance to environmental stresses, and capacity to synthesize allelochemicals have all contributed to the ability of $S$. trilobata o rapidly invade and cause significant damage to natural ecosystems and commercial plantations (Wang et al., 2012a, b). Also has used as green manure in rice and the aqueous extracts of $S$. trilobata inhibited the growth of the root on rice (Nie et al., 2004).

This study aimed to assess the allelopathic potential of S. trilobata, popularly known as beach Romerillo in Cuba, as well as to measure how it affects weeds, the germination and growth of some crops, and the relationship with the microflora activity and soil properties.

\section{MATERIAL AND METHODS}

The tests were conducted at the Agricultural Research Center (CIAP), from University "Marta Abreu" of Las Villas (UCLV), VC. Cuba. The phytochemical screening was conducted in the laboratories of Chemistry and Pharmacy Faculty in this University.

Use and soil analysis: Soil samples (50 kg) were collected according to Hernandez et al. (1999), collecting seven points on a central diagonal in the field from the Experimental Station "Alvaro Barba Machado" located (UCLV). The soil was sieved $(\varnothing 4 \mathrm{~mm})$ and was subsequently sterilized.

Plant material: S. trilobata plants were collected in flowering stage, in areas of the campus (UCLV). The procedure was obtained residues of plants, according to Narwal (2009) and John et al. (2006). The dried residues of each species were crushed to particles of about $1 \mathrm{~mm}$ diameter, by using a mill (Veb Nossen8255 , RDA). The milled was stored in paper bags under dark conditions and low humidity until use. Seeds of Amaranthus spinosus and Portulaca oleracea were collected on the same places (UCLV), selecting healthy, vigorous plants with good fruit production.

Sterilization of equipment and seed treatment: The floor and the Petri dishes $(\varnothing 150 \mathrm{~mm}, \mathrm{~h}=25 \mathrm{~mm})$, which contained a Whatman No. 1 filter paper, were autoclaved at $120{ }^{\circ} \mathrm{C}$ and $1.5 \mathrm{~atm}$ for 30 minutes. After autoclaving, each material was dried $\left(45^{\circ} \mathrm{C}\right.$, 24 hours) in an oven before being used in various experiments. The seeds used in each 
experiment in vitro were previously disinfected with sodium hypochlorite $1 \%$ in 3 minutes, for 3-10 minutes then washed with sterile distilled water, becoming ready for use. For Amaranthus spinosus were scarified with sulfuric acid $\left(\mathrm{H}_{2} \mathrm{SO}_{4}\right) 50 \%$ for 5 minutes and then water washed for 10 minutes (Aliero, 2004).

\section{Effects of residues from S. trilobata on the germination and growth of weeds}

Sialitic brown soil samples were mixed with residues in the established dose (Table 1) and distributed in polystyrene containers (trays), divided inside, forming "individual plots" of $0.26 \mathrm{~m} \mathrm{x} 0.32 \mathrm{~m}\left(0.083 \mathrm{~m}^{2}\right)$ and $0.05 \mathrm{~m}$ deep $\left(0.00415 \mathrm{~m}^{3}\right)$. A completely randomized design with three treatments, consisting of three residues doses from each donor species and a control with no residues was used. Each treatment had four replicates and the assay was repeated twice.

Table 1 - Residues concentration S. trilobata applied to weeds

\begin{tabular}{|c|c|c|}
\hline \multirow{2}{*}{ Donor } & $\begin{array}{c}\text { Dose } \\
(\%)\end{array}$ & $\begin{array}{c}\text { Equivalent } \\
\left(\mathrm{g} \mathrm{m}^{-2}\right)\end{array}$ \\
\hline \multirow{3}{*}{ S. trilobata } & 100 & 630 \\
\cline { 2 - 3 } & 50 & 315 \\
\cline { 2 - 3 } & 25 & 160 \\
\hline
\end{tabular}

Soil moisture was maintained by applying daily irrigation with sufficient water. At 30 days of experiment were recorded: number of weeds species and the total dry biomass. Weed species were identified using botanical descriptors according to Rodríguez et al. (1985), Sánchez \& Uranga (1990) and Roig (1975).

\section{Activity of residues from S. trilobata on the germination and growth of crops}

The effect of both donor residues species, previously disinfected seed of Solanum lycopersicum (Tomato), Allium cepa (onion), Brassica oleraceae (cabbage) and Raphanus sativus (radish) were tested. Twenty seeds of each species were placed in humidity chambers on Petri dishes $(\varnothing 150 \mathrm{~mm}, \mathrm{~h}=$ $25 \mathrm{~mm}$ ), as sialitic substrate Sialitic Brown soil and over this filter paper, on which the seeds are placed. All materials, including the soil were sterilized as was described before. A completely randomized design with four treatments was used. It consisted of three doses of residues from each donor species and four replications. (Table 2). At $10^{\text {th }}$ days of experiment the number of germinated seeds were evaluated and measured with a ruler millimeter length of rootlets and stems.

\section{Physical chemical properties and microbiological activity evaluated on treated soil with $S$. trilobata residues}

Residues of the donor species were mixed in two doses (25 and 100\%), on sialitic brown soil using $500 \mathrm{~cm}^{3}$ plastic containers (Table 2). They were watered every other day with water, maintaining the soil to $80 \%$ of field capacity. At 30 days a soil sample was taken and evaluations were performed. By counting serial dilutions, informed by Mayea et al. (1982), the number of colony forming units of microorganisms per gram of soil (CFU g-1) was assessed. Tests with microorganisms isolated from soil were made from $1 \mathrm{~g}$ of soil collected and diluted in sterile water in rate $(1: 10)$, afterwards, they were seeded in culture media and incubated at $28{ }^{\circ} \mathrm{C}$.

Table 2 - Conditions set out to assess the number of colony forming units of microorganisms per gram of soil

\begin{tabular}{|c|c|c|c|}
\hline Microorganism & Culture medium & Final dilution & Time of evaluation \\
\hline Total bacteria & Glycerin peptone agar & $1 / 100000$ & 48 hours \\
\hline Total fungi & Rose bengal agar & $1 / 1000$ & 48 hours \\
\hline Actinomycetes & Ammoniacal starch agar & $1 / 10000$ & 7 days \\
\hline Azotobacter spp. & Asbhys Medium & $1 / 1000$ & 48 hours \\
\hline Cellulolytic fungi & Müller agar & $1 / 1000$ & 15 days \\
\hline
\end{tabular}


Based on a sample of $100 \mathrm{~g}$ of soil from each treatment, chemical soil properties were determined: $\mathrm{pH}\left(\mathrm{H}_{2} \mathrm{O}\right), \mathrm{pH}(\mathrm{KCl})$, content of $\mathrm{P}_{2} \mathrm{O}_{5}, \mathrm{~K}_{2} \mathrm{O}, \mathrm{Ca}^{2+}, \mathrm{Mg}^{2+}, \mathrm{K}^{+}, \mathrm{Na}^{+}$; and the electrical conductivity of the soil solution and cation exchange capacity (CEC) commonly expressed by the value $\mathrm{T}$. These analyzes were performed with application of the Standards established by the MINAGRI and NRAG 837 (1986) was employed for the determination of the mobile forms of $\mathrm{P}$ and $\mathrm{K}$. Indices for evaluating the acidity NRAG 878 (1987). The NRAG 879 (1987) for exchangeable cations $\left(\mathrm{Ca}^{2+}, \mathrm{Mg}^{2+}, \mathrm{K}^{+}\right.$and $\left.\mathrm{Na}^{+}\right)$and the value T. Finally, total soluble salts, soluble cations, and anions were assessed in accordance with NRAG 889 (1988).

\section{Data processing and statistical analysis}

Data were statistically processed through the Statgraphics package Ver. 5.1 Plus for Windows. Analysis multiple comparison of proportions for total germination was used. To the remaining of variables parametric, ANOVA Duncan, Tukey or Bonferroni test was applied to detect statistical differences. When difference was assumed for non-parametric data, constrate by Kuskal wallis and Dunnett'C test was applied with Statistix package. 6. In all cases a 95\% confidence level was used.

\section{RESULT AND DISCUSSION}

\section{Effects of residues from S. trilobata on the germination and growth of weeds}

Figure 1 shows the effect of differents doses of $S$. trilobata residues and the inhibition germination on weed seed.
Same decrease of weed germination was achieved with 50 and $100 \%$ of residues, between 204 and 156 plants $\mathrm{m}^{-2}$. The lowest dose reduced at 394 the total of weeds, significantly different from the 575 plantas $\mathrm{m}^{-2}$ found in the control (Figure 2). Residues inhibited germination of dicotyledonous, but only the highest dose $100 \%\left(630 \mathrm{~g} \mathrm{~m}^{-2}\right)$ had a negative effect on monocotyledons to 87 plants $\mathrm{m}^{-2}$.

As the dry weight of weeds after application of $S$. trilobata residues was evidently observed that all treatments affected the dry weight values, remain very low $\left(8.8-0.49 \mathrm{~g} \mathrm{~m}^{2}\right)$ when used waste $25-100 \%$, compared to the control which obtained $29.4 \mathrm{~g} \mathrm{~m}^{-2}$ (Fig ure 3).

Similar to these results Abeysekera et al. (2005) demonstrated the inhibitory effect of Spehenoclea zeylanica (Sphenocleaceae) residues on the germination and biomass production of Echinochloa crus-galli and Leptochloa chinensis, two major weeds in rice fields.

Recent results by Sobrero et al. (2004) confirm the reports of other authors (Bonasera et al., 1979; Castro et al., 1983; Pope \& Thompson, 1984; Rice, 1984; Alves et al., 1986) on allelopathic potential of W. glauca, considerably steeper higher in leaves, which have a marked inhibition on germination and growth of the radicle of species Lycopersicum esculentum (tomato), Cucumis sativus (cucumber) and Raphanus sativus (radish).

\section{Activity of residues from S. trilobata on the germination and growth of crops}

Figure 4 show that a residue of $S$. trilobata does not affect the germination of onions,

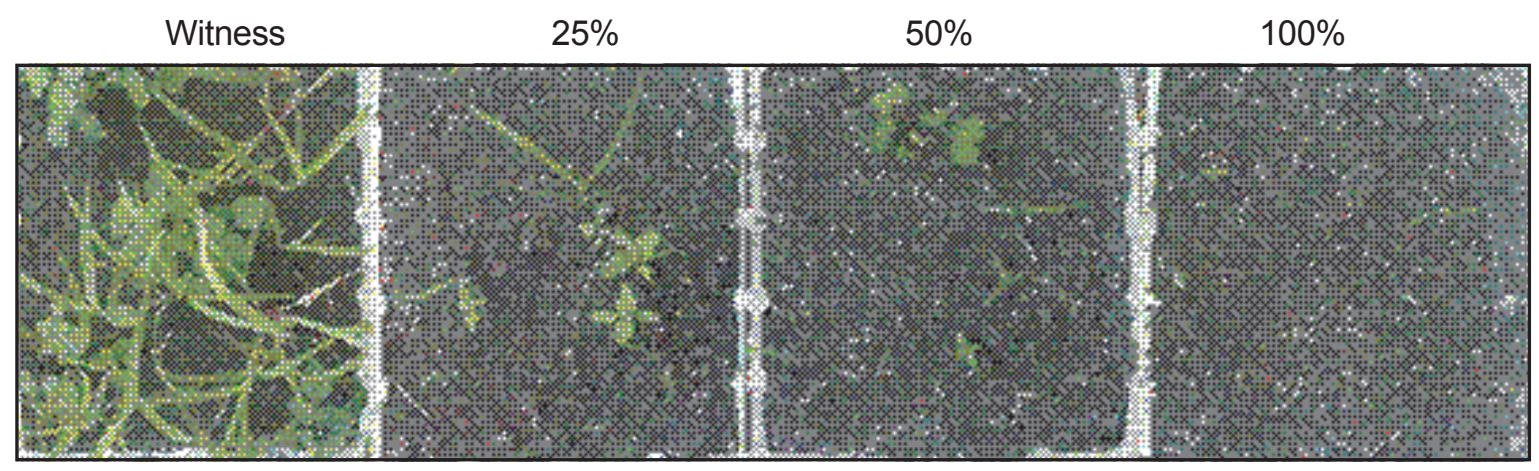

Figure 1 - Effect of S. trilobata residues on weed emergence after 30 days of experiment. 


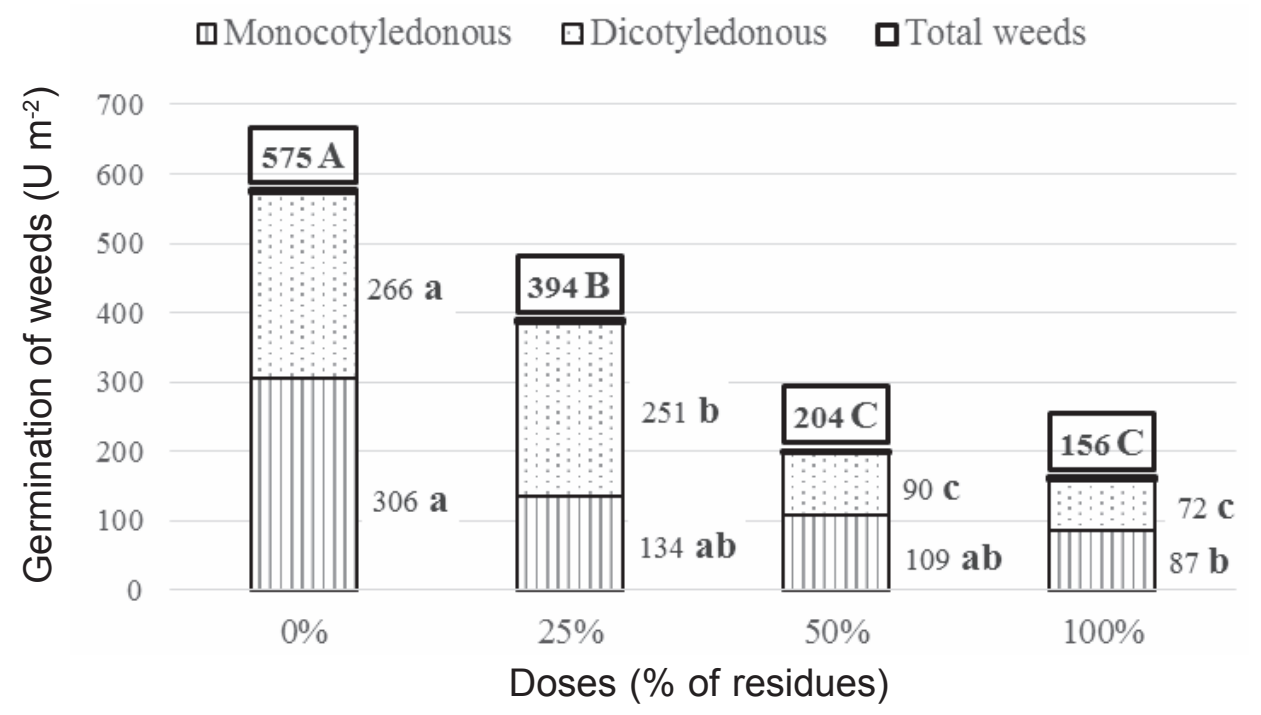

While, Duncan analysis was used, to find differences on the weeds total, with a confidence level of $\mathrm{p}<0.05$.

Figure 2 - Shows the inhibitory effect of S. trilobata on the germinaation for Monocotyledonous and Dicotyledonous species, the same letters do not have a difference when applied Dunnett'C.

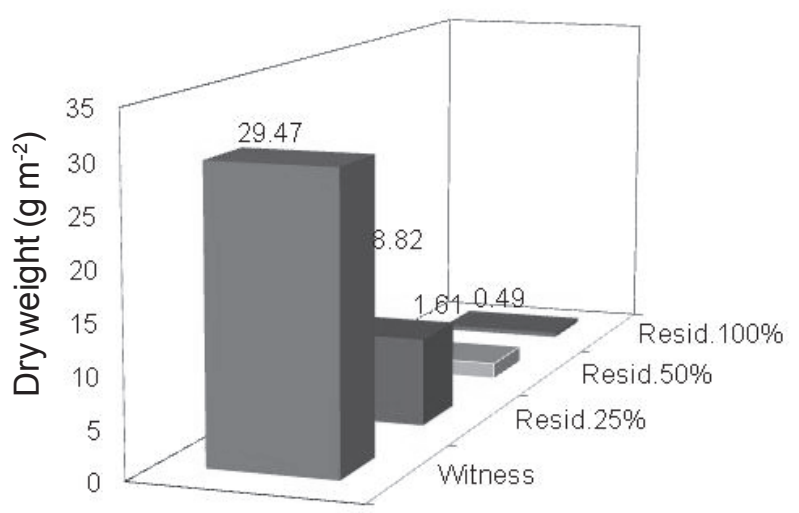

Figure 3 - Dry biomass reduction with different dose of residues of $S$. trilobata applied to the major weeds.

while it stimulates radish and tomato. However, when applied to $50 \%$ of waste it caused different responses, the stimulus of tomato, but cabbage was inhibited.

In this regard, Gonçalves et al. (2001) stated that extracts from roots of other weeds, such as Rottboellia cochinchinensis Clayton (Poaceae), did not affect germination of onion, but was stimulated with extracts of foliage between (0.1-1.0 $\left.\mathrm{g} \mathrm{L}^{-1}\right)$.

They have also proven Ghayal et al. (2007), the allelopathic potential of weeds Senna uniflora Irwin \& Barneby which produced a significant stimulation of germination of radish and mustard (Brassica juncea) Czem. with the lowest concentrations $\left(0.0025-0.005 \mathrm{~g} \mathrm{~mL}^{1}\right)$, while the highest $\left(0.015\right.$ to $\left.0.02 \mathrm{~g} \mathrm{~mL}^{-1}\right)$ produced inhibition of both species.

However, the results obtained in this study are different from those obtained by Dos Santos et al. (2001), who found that extracts Thelypteris scabra, did not affect the germination of lettuce, onion but inhibited at all concentrations tested.

The residues effect of $S$. trilobata on growth depended largely crop species and doses used (Figure 5).

You can watch the remains S. trilobata inhibited growth epicótilo onion question that could only have significance in the shape of the bulb. These showed the greatest inhibition observed in the radicle tomato hypocotyl of radish, although the latter could not be relevant, considering the issues raised by Guencov (1971), who said that the radish, whose commercial fruit is root thickened, could not have great importance little growth achieved by the hypocotyl, regarding the development of tuberous root. Moreover S. trilobata stimulating effects on tomato hypocotyl and both (hypocotyl and radicle) in cabbage were tested. 


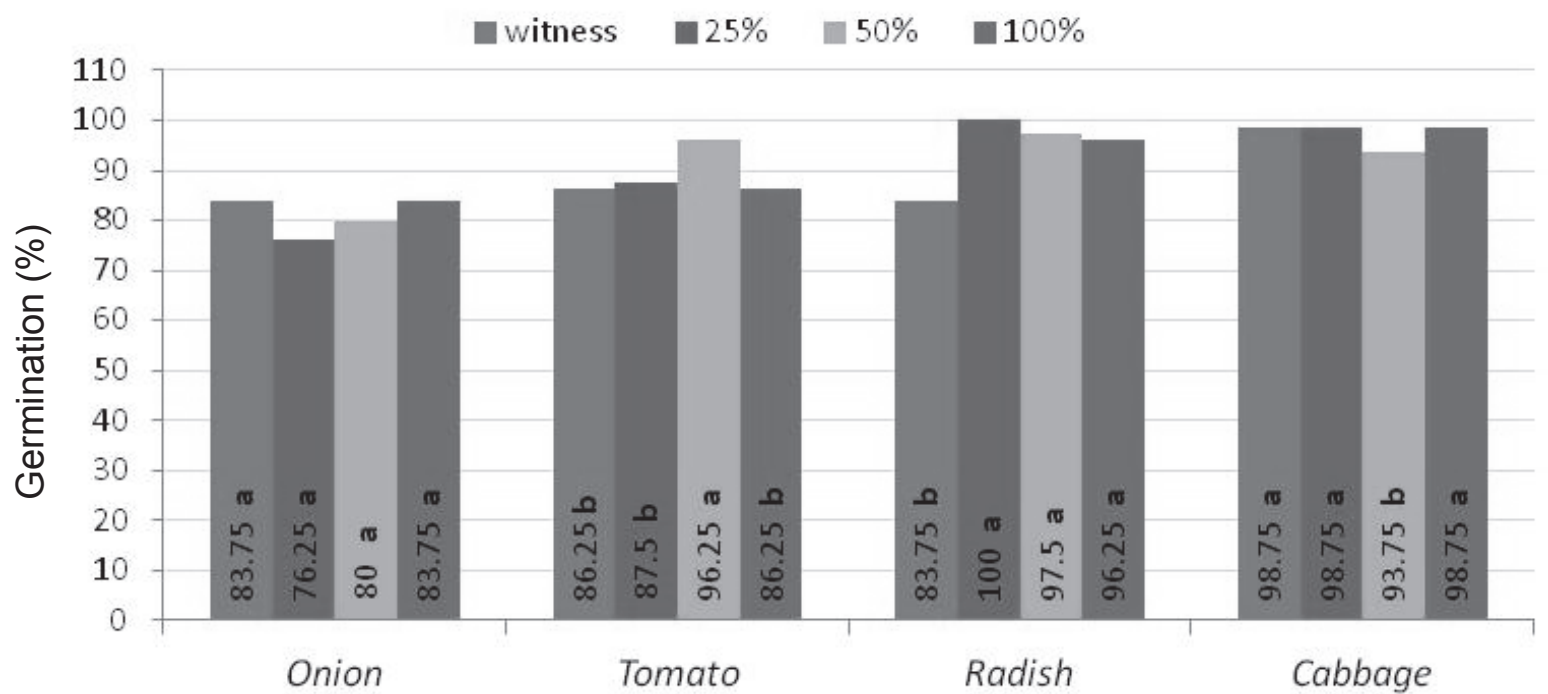

Figure 4 -Effect of doses residues of S.trilobata on the germination of crops. Different letters for each crop residue treated have statistical difference $(\mathrm{p}<0.05)$.

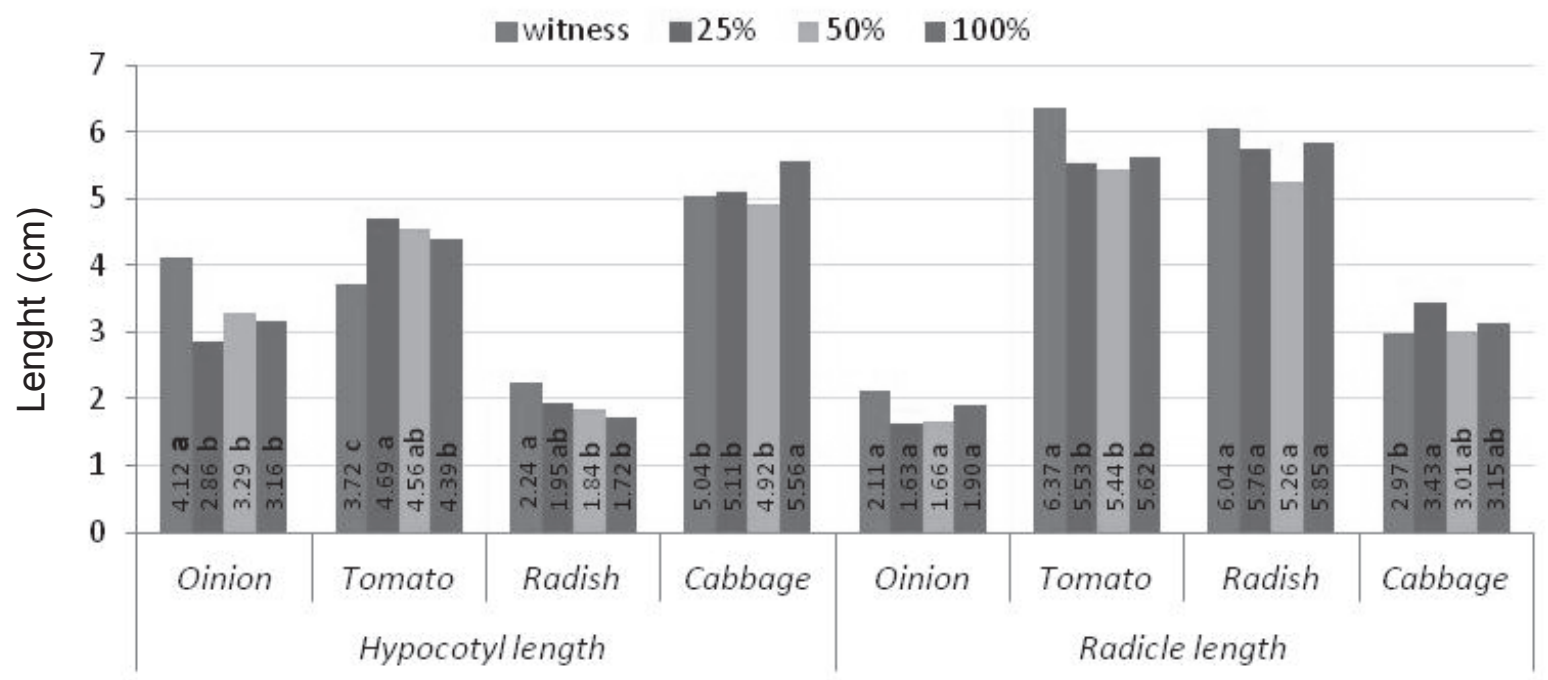

For the hypocotyl on radish and onion, the Kuskal Wallis analysis was applied. Different letters in residue of each treatment have statistical difference $(\mathrm{p}<0.05)$.

Figure 5 - Effect of doses residues of S. trilobata on the hypocotyl growth and radicle of crops. Different letters for each residue, on crop and organs, were treated by Bonferroni test.

When analyzing the effect on hypocotyl growth with different doses of residues $S$. trilobata on these crops were observed changes in the response by species.

In onion: three doses had a negative effect on hypocotyl and differ of control. In tomato was quite the opposite, there was an estimulation of this organ with the three doses applied, being the best (25 and 50\%) of waste. The radish growth slowed when any dose was applied, but only differ 50 and 100\% against control. In cabbage there were only stimulated hypocotyl length when the maximum dose $(100 \%)$ was applied, the others do not differ control.

For the growth of radicle were observed results contrasts between the cultures treated with waste $S$. trilobata. 
The onion and radish no differences were found regarding control, while in tomato radicle growth was inhibited. In contrast to the cabbage, all doses of waste produced a stimulus radicle length, differing for control. For the growth of the radicle there were different responses between cultures treated with waste $S$. trilobata.

For onion and radish no differences were found compared to control, while in tomato radicle growth was inhibited. In contrast to the cabbage, all doses residues produced a stimulus radicle length, differing of control.

Nie et al. (2005) showed that extracts of S. trilobata have a depressing effect of metabolism of rice seedlings, which suffered a reduction in weight, root activity, chlorophyll content, photosynthetic rate, respiration rate and greater membrane permeability.

Moreover, Nakano (2006) found that Alangium premnifolium Ohwi inhibited the root growth of Sesamum indicum, Lactuca sativa, Lepidium sativum, Celosea cristata, while it did not affect the root of Allium fistulosum, Brassica rapa, Phleum pratense and Triticum aestivum. However, it did not affect the growth of the stem of the plant species used except for Lactuca sativa and Lepidium sativum, instead, it inhibited.

An (2005) explained that the plants may defend themselves by means of such allelochemicals in several ways. Phenolics, particularly flavonoids, are considered protectors against UV ray. Under stressful conditions, such as drought or insufficient nutrients, allelochemicals may inhibit the growth of other plants.

The results are contrasting to $S$. trilobata, according to Sobrero et al. (2004), who claim that it is important that part of the donor plant used. These worked with aqueous extract of leaves of $W$. glauca and observed greater phytotoxic potential reduction in the length of the radicle, than when using extract prepared from rhizomes. For $50 \%$ of the leaf extract in radish and tomato recorded a reduction relative to the control of 76.21 and $89.74 \%$ respectively. However, for those same concentrations of the extract, an increased length of radish compared to control (28.33\%) and a tomato reduction $(22.37 \%)$ were recorded.

Evidently, the main changes in the growth and development of plants are given as responses to hormonal proportions which can induce growth, rejuvenation and finally the development of the plant in general. It could be that the varied responses in the growth of stems and roots is due to the sensitivity that show the different organs to hormone levels, specifically AIA, being the most sensitive roots, followed by the buds and stems (Acosta et al., 2001).

\section{Assessment of the physical-chemical and microbiological properties, of soil residues treated with residues of $S$. trilobata}

Figure 6 shows the stimulus of residues on soil microflora. S. trilobata activity on bacteria is highlighted, doubling the number of soil (UFC g-1 ${ }^{-1}$ to a $5678=1.03 \times 107 \mathrm{CFU} \mathrm{g}^{-1}$. Also, S. trilobata produced a stimulus on total cellulolytic fungi and total fungus; without affecting the populations of Azotobacter.

Mallik \& Williams (2005) suggest that plant extracts have been commonly found as stimulating factors populations of microorganisms in soil. They informed has detected that aqueous extracts of roots of Chenopodium spp. (quinoas) were more stimulanting than some organic compounds, which increases up to four times the concentration of Bradyrhizobium japonicum in broth culture.

Singh \& Rai (1981) have reported aqueous extracts of leaves mustard, can cause the barley stimulation and also of the some saprophytic microorganisms and phytopathogenic fungi. While filtered extracts of C. album and C. viridis caused a stimulation of nodulation by Bradyrhizobium japonicum on soybean using specific culture means.

\section{Physico-chemical properties of soil treated with residues of $\mathbf{S}$. trilobata}

It was observed that the $\mathrm{pH}\left(\mathrm{H}_{2} \mathrm{O}\right)$ was affected when the residues were applied to soil, which generated a decrease until 7.67, although it still remained at basic level 


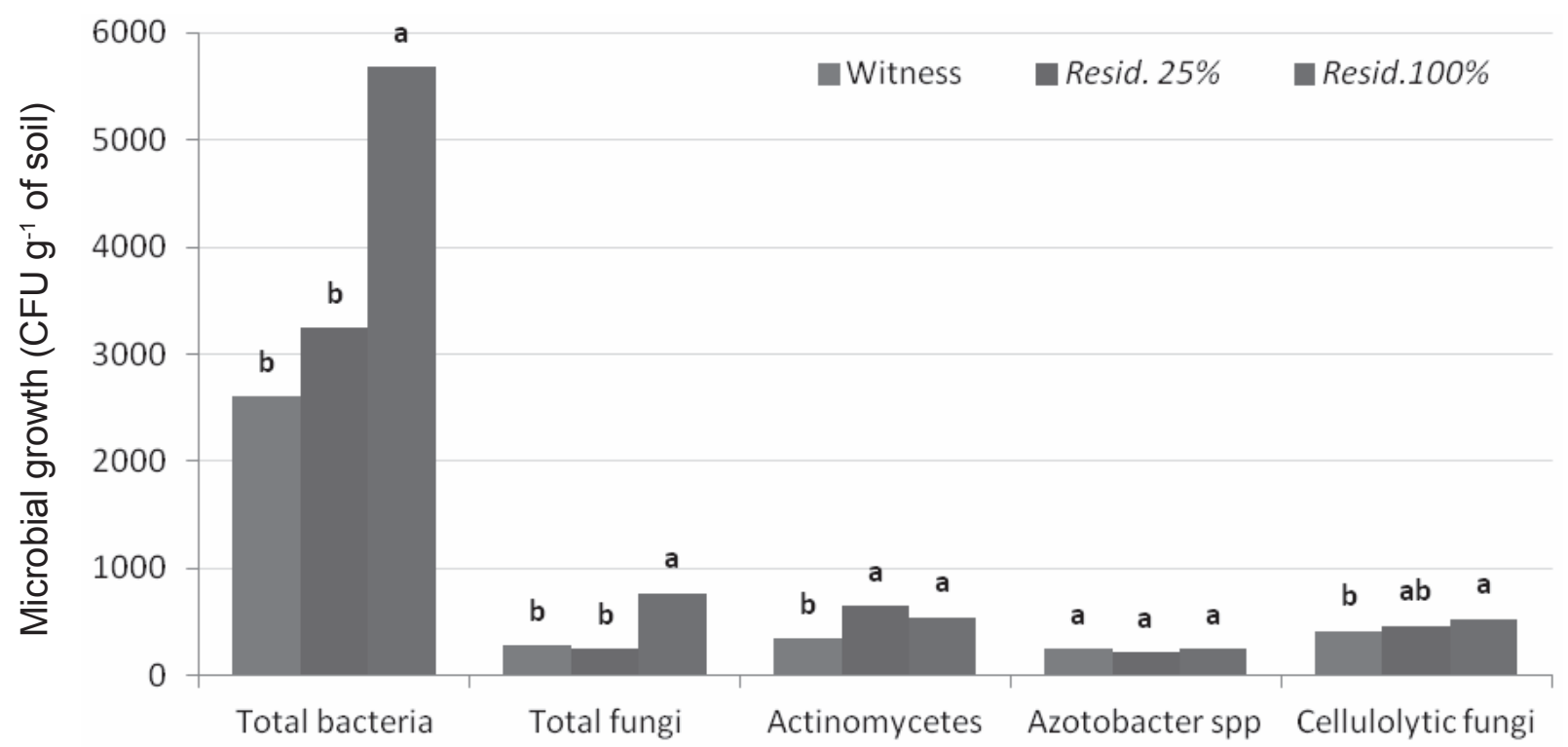

Figure 6-Effects of residues of S. trilobata applied in different concentrations on soil microbial activity. Different letters in the same group of microorganisms differ by Tukey $\mathrm{p}<0.05$.

(Table 3). A slight increase in the level of organic matter $(\mathrm{OM})$ soil was observed, when the residues were applied against the control, but without difference between doses. This corroborates with Norouzi et al. (2014) who, when incorporating plant residues, found a decrease in soil $\mathrm{pH}$.

The electrical conductivity of the soil solution increased for all treatments, when the dose of residues applied were increased.

The $(\mathrm{Na}+)$ was significantly higher with the higher dose of $S$. trilobata and doubled the content of this element in the soil. Such levels in sialitic brown soil are normal and do not affect crops (Pizarro, 1985).

Batish et al. (2005), after evaluating waste Parthenium hysterophorus (Asteraceae) on soil properties with some indicator plants (horseradish and mustard), stressed that growth inhibition was not attributed to increased nitrogen $(\mathrm{N})$ for control, but if it was related to the content of phenols, which play an important role in the changes of chemical nutrients in the soil, which is evidenced by effects on $\mathrm{pH}, \mathrm{MO}$, electrical conductivity and availability of mineral nutrients on the ground. This is favored with crop age and phytotoxic residues of the species.
Therefore, waste of S. trilobata produce inhibitory effect on the weeds germination (31.6-72\%), that increasing with the applied dose. All doses of residues of this specie, inhibited the germination dicotyledonous, but only the maximum concentration affect the monocotyledons. The residues did not affect the onion germination, but stimulated in radish and tomato, while the dose of $50 \%$ produced tomato stimulation and the inhibition of cabbage. When analyzing the effect of residues on hypocotyl growth on different species, changes in the response by species were contrasting. In onion three doses had to a negative effect on hypocotyl, while tomato was stimulated. In radish the growth was slowed with any dose applied, only 50 and $100 \%$ has differences respect to control. In cabbage were only stimulated the hypocotyl length when the maximum dose $(100 \%)$ was applied. For the radicle growth, were observed results contrasts between the cultures treated. For the onion and radish no differences on radicle the along, while that in tomato the growth was inhibited. However, a different response in cabbage, where all doses stimulated the growth of the radicle was obtained. The dry mass of weed was affected by increase the residue doses $\left(8.8-0.49 \mathrm{~g} \mathrm{~m}^{-2}\right)$, however the soil microflora was stimulated, while the population of Azotobacter spp. were 
not affect. Soil properties were affected, the level of organic material, $\mathrm{Na}+$ and electrical conductivity had increased, while the $\mathrm{pH}\left(\mathrm{H}_{2} \mathrm{O}\right)$ decreased a few, however it remains basic.

\section{LITERATURE CITED}

ABEYSEKERA, A. S. K.; HERATH, H. M. S.; WICKREMA, U. B. Allelopathic potential of goose weed (Spehenoclea zelanica) on rice weeds in Sri Lanka. In: WORLD CONGRESS ON ALLELOPATHY, 4., 2005, Australia. [en línea]. <http://www.regional.org.au/au/ allelopathy/2005/2/1/2469_jayakumarm.htm>. [22/6/2007].

ACOSTA, E. M.; SÁNCHEZ, B. J.; BAÑÓN, A. M. Auxinas; fundamentos de fisiología vegetal. España: 2001. p. 305-323.

AKHTAR, S. et al. Allelopathic assessment of selected invasive species of Pakistan. Pak. J. Bot., v. 46, n. 5, p. 1709-1713, 2014.

ALIERO, B. L. Effects of sulphuric acid, mechanical scarification and wet heat treatments on germination of seeds of African locust bean tree, Parkia biglobosa. Afr. J. Biotechnol., v. 3, n. 3, p. 179-181, 2004.

ALVES, P. L. C. A. et al. Estudo dos efeitos inibitorios do caruru (Amaranthus retroflexus) sobre a germinacao e desenvolvimento de plántulas de pepino (Cucumis sativus). In: ALMEIDA, F. S. (Ed.). A alelopatia e as plantas. Londrina: IAPAR, 1986. p. 25.

AN, M. Mathematical modelling of dose-response relationship (Hormesis) in allelopathy and its application. Nonlinearity Biol. Toxicol. Med., v. 3, n. 2, p. 153-172, 2005.

BATISH, D. R. et al. Allelopathic interference of Parthenium hysterophorus residues in soil. Allelop. J., v. 15, n. 2, p. 267-274, 2005.

BONASERA, J.; LYNCH, J.; LECK, M. A. Comparison of the allelopathic potential of four march species. Bull. Torrey Bot. Club., v. 106, n. 3, p. 27-222, 1979.

CASTRO, P. R. C. et al. Efeitos alelopaticos de alguns extratos vegetais na germinacao do tomateiro (Lycopersicon esculentum Mill. Cv. Santa Cruz). Planta Daninha, v. 4, n. 2, p. 79-85, 1983.

DOS SANTOS, A. et al. Allelopathic potential of Thelypteris scabra (Presl.) Lellinger. First In: (REIGOSA, M. J.; PEDROL, N. (Ed.). EUROPEAN OECD ALLELOPATHY SYMPOSIUM.PHYSIOLOGICAL ASPECTS OF ALLELOPATHY, 1., 2002, Vigo, Espanha. Proceedings...Vigo, Espanha: Gamesal, 2001. 245 p.

GHAYAL, N. A. et al. Phytotoxic effects of Cassia uniflora leaf leachates on germination and seedling growth of radish (Raphanus sativus) and mustard (Brassica juncea).

Allelop. J., v. 19, n. 2, p. 361- 372, 2007.
GUENCOV, G. Fundamentos de la horticultura cubana. La Habana, Cuba: Editorial Pueblo y Educación, 1971. 295 p.

GONÇALVES, M. et al. Allelopathic potential of Rottboelia cochinchinensis (Lour.) Clayton (Poaceae). In: REIGOSA, M. J.; PEDROL, N. (Ed.). EUROPEAN OECD ALLELOPATHY SYMPOSIUM.PHYSIOLOGICAL ASPECTS OF ALLELOPATHY, 1., 2002, Vigo, Espanha. Proceedings...Vigo, Espanha: Gamesal, 2001. 245 p.

HERNÁNDEZ, A. et al. Nueva versión de clasificación genética de los suelos de Cuba. La Habana: AGRINFOR, 1999. $64 \mathrm{p}$.

JOHN, J. et al. Methodology of allelopathy research: 1 . Agroforestry systems. Allelop. J., v. 18, n. 2, p. 173-214, 2006.

LIJUN, X. et al. Allelochemical mediated invasion of exotic plants in China. Conference Title: Allelopathy research in Asia. In: INTERNATIONAL ALLELOPATHY CONFERENCE OF THE ASIAN ALLELOPATHY SOCIETY, 1., 2009, Guangzhou, China. Proceedings... Guangzhou, China; Allelop. J., v. 25, n. 1, p. 31-50, 2010.

MALLIK, B.; WILLIANS, R. Allelopathic growth stimulation of plants and microorganisms. Allelop. J., v. 16, n. 2, p. 175-198, 2005.

MAYEA, S.; NOVO, R.; VALIÑO, A. Introducción a la microbiología del suelo. La Habana, Cuba: Editorial Pueblo y Educación, 1982. 187 p.

NAKANO, H. Effects of syringoylglycerol 9-O-â-Dglucopyranoside on plant growth. Allelop. J., v. 18, n. 2, p. 309-314, 2006.

NARWAL, S. S. Suggested methodology for allelopathy laboratory bioassays. In: INTERNATIONAL ALLELOPATHY CONFERENCE OF THE ASIAN ALLELOPATHY SOCIETY, 1., 2009, Guangzhou, China. Proceedings... Jodhpur, India: Scientific Publishers, 2009. $332 \mathrm{p}$.

NIE C. R. et al. Allelopathic potentials of Wedelia trilobato L. on rice. Acta Agron. Sinica, v. 30, n. 9, p. 942-946, 2004.

NIE C. R. et al. Allelopathic potential of Wedelia trilobata L.: effects on germination, growth and physiological parameters of rice. Allelopathic potential of Wedelia trilobata L.: effects on germination, growth and physiological parameters of rice. In: HARPER, J. D. I. et al. (Ed.) WORLD CONGRESS ON ALLELOPATHY, 4., 2005, Wagga, New South Wales, Australia. Proceedings... Wagga: New South Wales, 2005. p. 469-472.

NORMA RAMAL DE LA AGRICULTURA. (NRAG) 837. Suelos. Análisis químico. Determinación de las formas móviles de Fósforo y Potasio. La Habana, Cuba: Ministerio de Agricultura 1986. 
NORMA RAMAL DE LA AGRICULTURA (NRAG) 878 Suelos. Análisis químico. Determinación de los índices del grado de acidez. Cuba: Ministerio de Agricultura, 1987.

NORMA RAMAL DE LA AGRICULTURA (NRAG) 879. Suelos. Análisis químico. Determinación de los cationes intercambiables y de la capacidad de intercambio catiónico. La Habana, Cuba: Ministerio de Agricultura, 1987.

NORMA RAMAL DE LA AGRICULTURA (NRAG) 889. Suelos. Análisis químico. Determinación de las sales solubles totales y de los aniones y cationes solubles en el extracto de acuoso, relación 1:5 suelo - agua. La Habana, Cuba: Ministerio de Agricultura, 1988.

NOROUZI, Y.; MUHAMMADI, G. R.; NOSRATTI, I. Poster 49. The allelopathic effect of some crops on johnsongrass seed germination. In: WORLD CONGRESS ON ALLELOPATHY, 7., Vigo, Espanha, 2014. Proceedings... Vigo, Espanha, 2014. 177 p.

OBAID, K. A.; QASEM, J. R. Allelopathic activity of common weed species on vegetable crops grown in Jordan. Allelop. J., v. 15, n. 2, p. 221-236, 2005.

PIZARRO, F. Drenaje agrícola y recuperación de los suelos salinos. 2.ed. Madrid, España: Editorial Agrícola Española, 1985. 542 p.

POPE, D. F.; THOMPSON, A. C. Biological activity of plant exudates and extracts. In: AMERICAN CHEMICAL SOCIETY NATIONAL MEETING. Proceedigns... Washington: American Chemical Society, 1984. p. 187.
RICE, E. L. Allelopathy. (2.ed). New York: Academic Press, 1984. 345 p.

RODRÍGUEZ, S. et al. Manual de malezas de la caña de azúcar en Cuba. Inglaterra: Imperial Chemical Industries, Plant Protection Division, 1985. 125 p.

ROIG, T. Diccionario botánico de nombre vulgares cubanos. 4.ed. La Habana, Cuba: Editorial Pueblo y Educación, 1975. 1142 p. II Tomos.

SÁNCHEZ, P.; URANGA, H. Plantas indeseables de importancia económica en los cultivos tropicales. La Habana, Cuba: Editorial Científico - Técnica, 1990. 167 p.

SINGH, D.B.; RAI, B. Effects of leaf extracts of mustard and barley on growth behavior of some Phylloplane microfungi. Bull. Torrey Bot. Club, v. 108, n.4. p. 419-429, 1981.

SOBRERO M. T.; OCHOA, M.; DEL C.; CHAILA, S. Potencial alelopatico de Wedelia glauca: efecto sobre especies hortícolas. Planta Daninha, v. 22, n. 1, p. 71-75, 2004.

WANG, R. L. et al. Effects of simulated acid rain on the allelopathic potential of invasive weed Wedelia trilobata. Allelop. J., v. 30, n. 1, p. 23-32, 2012 a.

WANG, R. L. et al. Simulated acid rain accelerates litter decomposition and enhances the allelopathic potential of the invasive plant Wedelia trilobata (Creeping Daisy). Weed Sci., v. 60 , n. 3 , p. $462-467,2012$ b.

WESTON, L. A. History and current trends in the use of allelopathy for weed Management. HortTechnology, v. 15, n. 3, p. 529-534, 2005. 